Penelitian

\title{
Efek Aplikasi Balsamum Peruvianum terhadap Persembuhan Luka Kastrasi Metode Terbuka Satu dan Dua Sayatan pada Anak Babi
}

\section{The Effect of Balsamum Peruvianum Application on The Healing of Castration Wounds with The One- and Two-Incision Open Method in Piglets}

\author{
Gunanti', Dwi Utari Rahmiati', Viyata Pratiwi Risky² \\ 'Divisi Bedah dan Radiologi, Departemen Klinik Reproduksi dan Patologi, Fakultas Kedokteran Hewan, \\ Institut Pertanian Bogor \\ ${ }^{2}$ Mahasiswa Program Sarjana Fakultas Kedokteran Hewan Institut Pertanian Bogor \\ *Penulis untuk korespondensi: gunantisoe@apps.ipb.ac.id \\ Diterima 20 Desember 2020, Disetujui 14 Mei 2021
}

\begin{abstract}
ABSTRAK
Tahapan pascaoperasi merupakan bagian penting dalam tindakan operasi. Persembuhan luka merupakan proses usaha untuk memperbaiki kerusakan yang terjadi pada kulit. Balsamum peruvianum merupakan resin dari pohon Myroxylon balsamum dengan kandungan asam sinamat yang dapat merangsang proses persembuhan luka, sekaligus memiliki kandungan benzyl benzoate yang berfungsi sebagai antiseptik alami. Penelitian ini bertujuan mengevaluasi efek aplikasi Balsamum peruvianum dalam persembuhan luka kastrasi dengan metode terbuka, satu dan dua sayatan pada anak babi. Hewan coba yang digunakan adalah anak babi yang telah dikastrasi berusia satu bulan dan terbagi menjadi dua kelompok, yaitu kastrasi satu sayatan dan dua sayatan masing-masing tiga ekor sampel. Anak babi masing-masing dibersihkan lukanya dua kali sehari selama dua minggu pascaoperasi dengan menggunakan kapas dan rivanol kemudian dioleskan Balsamum peruvianum menggunakan cotton bud. Pengamatan dilakukan secara makroskopis dan metode dinilai dengan skala 1 untuk sembuh sempurna dan 5 untuk luka basah. Data yang didapat kemudian diolah menggunakan Aplikasi SPSS V.20 dan diuji menggunakan Independent Sample T Test dengan selang kepercayaan $95 \%$. Hasil penelitian menunjukkan bahwa tidak ada perbedaan waktu persembuhan yang nyata antara dua kelompok. Kelompok babi satu sayatan memiliki waktu persembuhan rata-rata lebih singkat.
\end{abstract}

Kata kunci: Balsamum peruvianum, kastrasi, persembuhan luka

\begin{abstract}
The postoperative stage is an important part of a surgery. Wound healing is an attempt to repair the damage done to the skin. Balsamum peruvianum is a resin from the Myroxylon balsamum containing cinnamic acid to stimulate wound healing and benzyl benzoate as a natural antiseptic. This study aimed to evaluate the effect of Balsamum peruvianum application on the healing of castration wounds using the one- and two-incisions open method in piglets. The experimental animals were castrated one-month old piglets divided into two groups, one- and two-incision castration, with three samples each. The wound of each piglet was cleaned twice a day for two weeks postoperatively using cotton swabs and rivanol and rub with Balsamum peruvianum using cotton buds. The observation was conducted macroscopically by giving a rating, 1 for complete healing and 5 for wet wounds. The data obtained were then processed using the SPSS V.20 and tested using a Independent Sample T Test with a 95\% confidence interval. The results showed there was no significant difference in healing time between the two groups. The one-incision group had a shorter average healing time.
\end{abstract}

Keywords: Balsamum peruvianum, castration, wound healing 


\section{PENDAHULUAN}

Sterilisasi organ reproduksi merupakan tindakkan mengangkat, mengeluarkan dan menghilangkan organ reproduksi yang dilakukan secara aseptis. Pada hewan jantan sterilisasi dilakukan dengan cara kastrasi dan pada hewan betina dilakukan dengan cara ovariektomi atau ovariohisterektomi (Rahmiati et al., 2020). Kastrasi adalah suatu tindakan yang sengaja dilakukan untuk menghilangkan fungsi dari alat reproduksi dengan jalan mematikan sel kelamin jantan sehingga tidak mampu menghasilkan keturunan (Amiruddin et al., 2015).

Kastrasi dapat meningkatkan produktivitas ternak potong (Priyanto et al., 2019) dan mereduksi sifat temperamen, sehingga cenderung memiliki aktivitas gerak yang sedikit (Kuswati et al., 2016). Pada anak babi kastrasi dilakukan untuk mengurangi ekspresi perilaku seekor anak babi jantan. Seekor anak babi jantan dapat menampilkan berbagai perilaku yang tidak diinginkan, termasuk agresi terhadap manusia dan hewan peliharaan lainnya, perilaku seksual, dan penandaan teritorial dengan urin (Østevik et al., 2012).

Tahapan pascaoperasi merupakan bagian penting dalam suatu tindakan operasi. Penanganan pascaoperasi sangat penting karena dapat mempengaruhi kesembuhan hewan (Theresa et al., 2013). Perawatan pascaoperasi bertujuan untuk mengurangi komplikasi akibat pembedahan, mempercepat persembuhan, dan mengembalikan fungsi tubuh semaksimal mungkin seperti praoperasi. Adapun yang perlu diperhatikan pada kegiatan pascaoperasi antara lain makan, minum, defekasi, urinasi, dan pemeriksaan fisik hewan hingga hewan tersadar dari anestesi. Setelah hewan sepenuhnya sadar, perlakuan pascaoperasi tetap dilakukan dan dipantau. Hewan tetap dipantau hingga luka jaringan menjadi kering (Jitowiyono \& Kristiyanasari, 2010).

Persembuhan luka merupakan proses usaha untuk memperbaiki kerusakan yang terjadi pada kulit. Proses persembuhan luka dipengaruhi oleh beberapa faktor yaitu usia, vaskularisasi, nutrisi, kegemukan, obat-obatan, personal higiene, dan stres (Nurani et al., 2015). Proses perbaikan jaringan atau persembuhan luka terjadi dalam beberapa fase yaitu, fase hemostasis, fase inflamasi, fase proliferasi, dan fase maturasi (Marti et al., 2017). Menurut Taylor et al. (2011), terdapat beberapa prinsip dalam persembuhan luka yaitu; 1) kemampuan tubuh untuk menangani trauma jaringan, yang dipengaruhi oleh luasnya kerusakan dan keadaan umum kesehatan; 2) respon tubuh pada luka lebih efektif jika nutrisi yang tepat tetap dijaga; 3 ) respon tubuh secara sistemik pada trauma, aliran darah ke dan dari jaringan yang luka; 4) keutuhan kulit dan mukosa membran disiapkan sebagai garis pertama untuk mempertahankan diri dari mikroorganisme, dan; 5) persembuhan normal ditingkatkan ketika luka bebas dari benda asing tubuh termasuk bakteri.

Pengobatan luka pada umumnya masyarakat menggunakan povidone iodine $10 \%$ sebagai antiseptik (Dewiyanti et al., 2009). Pemberian antibiotik digunakan untuk mengurangi dan menekan infeksi bakteri sehingga tidak terjadi infeksi sekunder. Pemberian antiinflamasi dan analgesik digunakan untuk mengurangi rasa sakit serta mencegah peradangan (Fossum, 2019). Kelemahan antibiotik adalah resisten bakteri, serta hipersentisivitas, sedangkan kelemahan dari penggunaan antiseptik adalah bersifat iritatif dan toksik jika masuk kedalam pembuluh darah serta dalam penggunaan yang berlebihan dapat menghambat proses granulasi luka (Haris, 2009).

Pengguaan obat-obatan tradisional yang berasal dari alam dapat digunakan untuk persembuhan luka. Pengobatan tradisional sendiri merupakan pengobatan dengan menggunakan obat-obatan atau ramuan tradisional dari bahan alam yang berasal dari tumbuhan, mineral, hewan atau campuran bahan tersebut yang secara tradisional telah digunakan untuk pengobatan berdasarkan pengalaman (Syukur \& Hermani, 2002). Pengobatan tradisional yang dilakukan dalam penelitian ini adalah dengan memanfaatkan tumbuhan yang memiliki efek menyembuhkan luka terbuka yaitu Balsamum peruvianum.

Balsamum peruvianum adalah resin yang diproleh dari pohon dengan cara membuat sayatan pada kulit batang pohon Myroxylon balsamum. Pohon Myroxylon balsamum ini memiliki kandungan yang dapat merangsang proses persembuhan, sekaligus sebagai antiseptik alami. Asam sinamat, salah satu kandungannya, telah dianggap bermanfaat saat diaplikasikan (Schottenhammer, 2020).

\section{BAHAN DAN METODE}

Penelitian dilaksanakan selama dua bulan pada bulan Januari hingga Februari 2020. Penelitian dilakukan di Kandang Unit Pengelolaan Hewan Laboratorium, Fakultas Kedokteran Hewan, Institut Pertanian Bogor. Bahan penelitian adalah anak babi yang berusia 1 bulan sebanyak enam ekor, Balsamum peruvianum, rivanol. Alat penelitian yang digunakan adalah kandang, cotton bud, dressing tissue forceps, kapas, kasa. 
Hewan percobaan yang digunakan adalah 6 ekor anak babi berjenis kelamin jantan. Keenam anak babi diberi vaksin hog cholera. Tiga ekor anak babi yang diberi nama babi 1, babi 2, dan babi 3 dikastrasi dengan metode terbuka satu sayatan, sedangkan tiga ekor anak babi yang diberi nama babi 4, babi 5, dan babi 6 dikastrasi dengan metode terbuka dua sayatan. Anak babi masingmasing dibersihkan lukanya dua kali sehari selama dua minggu pascaoperasi dengan menggunakan kapas dan rivanol kemudian dioleskan Balsamum peruvianum menggunakan cotton bud. Seluruh prosedur yang dilakukan dalam penelitian ini telah disetujui oleh Komisi Etik Hewan Fakultas Kedokteran Hewan IPB dengan nomor sertifikat 158/KEH/SKE/XII/2019.

Pemeriksaan makroskopis atau pengamatan luka dilakukan dengan metode pengamatan terhadap persembuhan luka. Persembuhan luka diukur dengan parameter berupa perlekatan atau penutupan luka pascaperlakuan, kemudian diberikan skoring (Febram et al., 2010). Sebanyak enam ekor anak babi percobaan ditandai secara individual dengan spidol permanen untuk membedakan antar- anak babi yang satu dengan yang lainnya. Pengamatan dilakukan setiap hari selama 14 hari pertama pascakastrasi dan dilakukan pencatatan skor persembuhan luka berdasarkan pengamatan. Luka dinilai dengan skor 1 sampai 5 sesuai dengan Tabel 1. Skor ini merupakan modifikasi dari skor persembuhan kastrasi anak babi (Sutherland et al., 2010).

Analisis data dilakukan dengan bantuan software Statistical Product and Service Solutions Version 20 (SPSS V.20). Uji yang dilakukan pada penelitian ini adalah uji Independent Sample T Test dengan selang kepercayaan $95 \%$. Data yang diperoleh dari hasil pengamatan makroskopis dianalisis secara deskriptif untuk mengetahui perbandingan perbedaan persembuhan luka antara kedua kelompok perlakuan.

\section{HASIL}

Persembuhan luka pada luka sayatan kastrasi metode terbuka satu sayatan dan dua sayatan diamati secara makroskopis pada masing-masing sampel. Hasil pengamatan menunjukkan bahwa luka

Tabel 1 Pengamatan persembuhan luka babi (Sutherland et al., 2010)

\begin{tabular}{|c|c|c|}
\hline Skor & Keterangan & Deskripsi \\
\hline 1 & $\begin{array}{l}\text { Luka menutup } \\
100 \%\end{array}$ & $\begin{array}{l}\text { Pengamatan makroskopis yang diamati yaitu } \\
\text { berupa penutupan luka } 100 \% \text { yang, dicirikan } \\
\text { dengan tidak ada keropeng, }\end{array}$ \\
\hline 2 & $\begin{array}{l}\text { Luka menutup } \\
75 \%\end{array}$ & $\begin{array}{l}\text { Pemangamatan makroskopis yang diamati yaitu } \\
\text { berupa penutupan luka } 75 \% \text { yang dicirikan } \\
\text { dengan teramati sedikit keropeng pada area in- } \\
\text { sisi, }\end{array}$ \\
\hline 3 & $\begin{array}{l}\text { Luka menutup } \\
50 \%\end{array}$ & $\begin{array}{l}\text { Pemangamatan makroskopis yang diamati yaitu } \\
\text { berupa penutupan luka } 50 \% \text { yang dicirikan } \\
\text { dengan teramati keropeng yang terbentuk sem- } \\
\text { purna di atas luka, tampak tebal dan bergelom- } \\
\text { bang, }\end{array}$ \\
\hline 4 & $\begin{array}{l}\text { Luka menutup } \\
25 \%\end{array}$ & $\begin{array}{l}\text { Pemangamatan makroskopis yang diamati yaitu } \\
\text { berupa penutupan luka } 25 \% \text { yang dicirikan } \\
\text { dengan teramati keropeng yang terbentuk sem- } \\
\text { purna di atas luka, tampak tipis, }\end{array}$ \\
\hline 5 & $\begin{array}{l}\text { Luka tidak me- } \\
\text { nutup }\end{array}$ & $\begin{array}{l}\text { Pemangamatan makroskopis yang diamati yaitu } \\
\text { luka tidak menutup dan teramati luka masih ter- } \\
\text { buka dan ada tanda darah segar. }\end{array}$ \\
\hline
\end{tabular}


sayatan semakin mengecil dan seluruh sampel mengalami persembuhan sempurna pada hari ke-14 (lihat Tabel 2) yang berbanding lurus dengan penurunan nilai skoring (lihat Tabel 3 dan Tabel 4). Semakin rendah derajat skoring, maka semakin baik tingkat penutupan luka kastrasi pada permukaan kulit. Tabel 3 menunjukan skoring derajat kesembuhan luka kastrasi pada anak babi metode terbuka satu sayatan, dan Tabel 4 menunjukan skoring derajat kesembuhan luka kastrasi pada anak babi metode terbuka dua sayatan.

Berdasarkan hasil pengamatan yang diperoleh pada Tabel 3 dan Tabel 4, keenam anak babi baik kastrasi dengan satu sayatan maupun dengan dua sayatan menunjukan pengurangan nilai skoring, setelah diamati pada hari ke -2, hari ke -4, hari ke 6 , hari ke -8 , hari ke -10 , hari ke -12 dan hari ke -14 yang berarti menunjukan persembuhan luka pada permukaan kulit. Hasil skoring menunjukan bahwa luka kastrasi pada anak babi dengan satu sayatan pada hari ke-10 lebih cepat mendapatkan nilai $1 \mathrm{di}$ bandingkan dengan luka kastrasi anak babi dengan dua sayatan.

Hasil ini menunjukan bahwa nilai skoring antara dua metode per hari pengamatan jika dibandingkan menggunakan uji Independent Sample T Test tidak menunjukkan perbedaan yang nyata $(>0.05)$. Hasil analisis disajikan pada Tabel 5 .

\section{PEMBAHASAN}

Persembuhan luka merupakan proses memperbaiki kerusakan yang terjadi pada kulit. Proses persembuhan luka secara alami akan melalui beberapa fase yaitu fase hemostasis, fase inflamasi, fase proliferasi, dan fase maturasi (Marti et al., 2017). Fase haemostasis terjadi pada saat jaringan terluka. Pembuluh darah pada jaringan terluka akan terputus dan menyebabkan pendarahan. Reaksi pertama bagian tubuh yang terluka akan berusaha menghentikan pendarahan dengan mengaktifkan faktor koagulasi intrinsik dan ekstrinsik, yang mengarah ke agregasi platelet dan formasi clot vasokontriksi, pengerutan ujung pembuluh darah yang putus (retraksi) dan reaksi haemostasis (Landén et al., 2016).

Fase inflamasi terjadi pada saat setelah terjadinya trauma sampai hari ke-5 pascatrauma. Setelah terjadinya luka, pembuluh darah yang rusak mengalami konstriksi dan retraksi disertai reaksi hemostasis karena agregasi platelet yang bersama serabut fibrin membekukan darah (Kalangi, 2014). Menurut Suriadi (2004), fase inflamasi merupakan suatu fase reaksi tubuh melakukan perlawanan terhadap infeksi dan sebagai jembatan antara jaringan yang mengalami luka dan pembentukan sel-sel baru. Berdasarkan metode skoring, skor atau nilai 5 dan 4 menunjukan kondisi persembuhan masih berada dalam fase inflamasi.

Tabel 2 Skoring hasil pengamatan persembuhan luka kastrasi metode terbuka dua sayatan

\begin{tabular}{cccccc}
\hline Skor 5 & Skor 4 & Skor 3 & Skor 2 & Skor 1 \\
\hline 16 & 41 & & & & \\
\hline
\end{tabular}

Tabel 3 Hasil nilai skoring pemeriksaan makroskopis terhadap persembuhan luka kastrasi metode terbuka dan satu sayatan

\begin{tabular}{cccccccc}
\hline \multirow{2}{*}{ Anak babi } & \multicolumn{7}{c}{ Waktu Pengamatan (Hari) } \\
\cline { 2 - 8 } & $\mathrm{H}-2$ & $\mathrm{H}-4$ & $\mathrm{H}-6$ & $\mathrm{H}-8$ & $\mathrm{H}-10$ & $\mathrm{H}-12$ & $\mathrm{H}-14$ \\
\hline 1 & 4 & 4 & 3 & 2 & 1 & 1 & 1 \\
2 & 4 & 4 & 4 & 3 & 2 & 1 & 1 \\
3 & 4 & 3 & 2 & 2 & 1 & 1 & 1 \\
\hline Rata-rata & \multirow{2}{*}{$4 \pm 0.00$} & $3.67 \pm 0.57$ & $3 \pm 1.00$ & $2.33 \pm 0.57$ & $1.33 \pm 0.57$ & $1 \pm 0.00$ & $1 \pm 0.00$ \\
\hline SD & & &
\end{tabular}

Keterangan: Skoring 1 (Luka menutup seluruhnya), skoring 2 (luka menutup 75 \%), skoring 3 (luka menutup $50 \%$ ), skoring 4 (luka menutup $25 \%$ ), skoring 5 (luka tidak menutup / terbuka). 
Tabel 4 Hasil nilai skoring pemeriksaan makroskopis terhadap persembuhan luka kastrasi metode terbuka dan dua sayatan

\begin{tabular}{|c|c|c|c|c|c|c|c|}
\hline \multirow{2}{*}{ Anak babi } & \multicolumn{3}{|c|}{ Waktu Pengamatan (Hari) } & \multirow[b]{2}{*}{$\mathrm{H}-8$} & \multirow[b]{2}{*}{$\mathrm{H}-10$} & \multirow[b]{2}{*}{$\mathrm{H}-12$} & \multirow[b]{2}{*}{$\mathrm{H}-14$} \\
\hline & $\mathrm{H}-2$ & $\mathrm{H}-4$ & $\mathrm{H}-6$ & & & & \\
\hline 4 & 5 & 4 & 4 & 3 & 2 & 1 & 1 \\
\hline 5 & 5 & 4 & 4 & 3 & 2 & 1 & 1 \\
\hline 6 & 4 & 4 & 3 & 3 & 2 & 2 & 1 \\
\hline $\begin{array}{l}\text { Rata-rata } \\
\pm \text { SD }\end{array}$ & $4.67 \pm 0.57$ & $4 \pm 0.00$ & $3.67 \pm 0.57$ & $3 \pm 0.00$ & $2 \pm 0.00$ & $1.33 \pm 0.57$ & $1 \pm 0.00$ \\
\hline
\end{tabular}

Keterangan: Skoring 1 (Luka menutup seluruhnya), skoring 2 (luka menutup $75 \%$ ), skoring 3 (luka menutup $50 \%$ ), skoring 4 (luka menutup $25 \%$ ), skoring 5 (luka tidak menutup / terbuka).

Fase proliferasi ditandai dengan pembentukan jaringan granulasi dalam luka yang diawali oleh aktivitas fibrolas mensintesis kolagen dan proteoglikan yang menghasilkan jaringan parut. Setelah terjadi luka, fibroblas akan aktif bergerak dari jaringan sekitar luka ke dalam bagian jaringan yang luka, kemudian akan berkembang serta mengeluarkan substansi yaitu kolagen, elastin, hyaluronic acid, fibronectin, dan proteoglycans, yang berperan dalam membentuk jaringan baru (Qomariah, 2014). Fase proliferasi diakhiri dengan tumbuhnya jaringan epitel yang berperan dalam meningkatkan aliran darah menuju area luka. Darah akan menyalurkan nutrisi dan oksigen untuk mempercepat proses persembuhan luka. Berdasarkan metode skoring, skor atau nilai 3 dan 2 sudah berada di fase proliferasi.

Fase Maturasi adalah fase penyerapan kembali jaringan yang berlebih dan pembentukan jaringan baru yang lebih sempurna dari fase proliferasi. Fase ini bertujuan untuk menyempurnakan terbentuknya jaringan baru menjadi jaringan yang lebih kuat. Waktu yang diperlukan pada fase ini dipengaruhi oleh usia, keturunan, jenis dan bentuk luka, lokasi luka, serta panjang dan intensitas dari periode inflamasi. Fase ini tidak mengembalikan keadaan kulit 100\% seperti sebelum terkena luka, tetapi hanya mengembalikan keadaan kulit sekitar $80 \%$ dari normal (Primadina et al., 2019). Berdasarkan metode skoring, skor atau nilai 1 sudah berada di fase maturasi.

Proses persembuhan luka dipengaruhi oleh faktor internal dan faktor eksternal. Faktor internal yaitu usia, anemia, penyakit bawaan, vaskularisasi, nutrisi, kegemukan, dan stress. Faktor eksternal yaitu obat obatan dan hygiene personal (Nurani et al., 2015). Menurut Marti et al. (2017), usia dapat berperan besar dalam laju persembuhan luka pascaoperasi Kastrasi pada usia hewan yang lebih muda memfasilitasi pengelolaan, dan mengurangi stres dan risiko penyakit akibat penurunan perkembangan testis.

Faktor persembuhan luka pada penelitian ini juga berkaitan dengan faktor eksternal seperti pemberian obat topikal yaitu Balsamum peruvianum dan rivanol. Balsamum peruvianum dapat meningkatkan aliran darah ke area luka dan juga membantu melawan bakteri serta mengurangi peradangan (Schottenhammer, 2020). Rivanol sebagai obat topikal memiliki sifat bakteriostatik dan tidak mengiritasi kulit atau iritatif, sehingga mencegah terjadinya infeksi yang dapat menghambat persembuhan luka (Kurniawaty et al., 2018).

Penggunaan obat lain juga dapat digunakan untuk persembuhan luka, salah satunya adalah povidone iodine $10 \%$ sebagai antiseptik (Dewiyanti et al., 2009). Akan tetapi penggunaan obat ini memiliki efek samping yang bersifat iritatif dan toksik jika masuk kedalam pembuluh darah serta dalam penggunaan yang berlebihan dapat menghambat proses granulasi luka (Haris, 2009). Menurut hasil penelitian Marti et al. (2017), penggunaan obat topikal seperti germicide dan aluminum powder spray sebagai tindakan pascakastrasi tidak meningkatkan kecepatan persembuhan luka. Pada penelitian ini penggunaan Balsamum peruvianum tidak menunjukkan percepatan persembuhan luka. Hasil skoring menunjukan bahwa luka kastrasi satu sayatan (lihat Tabel 3) menutup seluruhnya pada hari ke-10, dan hasil skoring pada luka kastrasi dua sayatan (lihat Tabel 4) menutup seluruh nya pada hari ke-12.

Menurut hasil penelitian Sutherland et al. 2010, luka kastrasi pada anak babi akan mengalami persembuhan luka pada 9 sampai 14 hari pascakastrasi dengan treatment iodine spray. Pada penelitian ini luka kastrasi satu sayatan (lihat Tabel 3) 
132 | Gunanti et al.

Tabel 5 Analisis data menggunakan uji Independent Sample T Test

\begin{tabular}{cccc}
\hline Hari pengamatan & $\mathrm{B} 1$ & $\mathrm{~B} 2$ & Signifikansi \\
\hline $\mathrm{H} 2$ & & & 0.184 \\
$\mathrm{H} 4$ & $4 \pm 0.00$ & $4.67 \pm 0.57$ & 0.423 \\
$\mathrm{H} 6$ & $3.67 \pm 0.57$ & $4 \pm 0.00$ & 0.184 \\
$\mathrm{H} 8$ & $3 \pm 1.00$ & $3.67 \pm 0.57$ & 0.184 \\
$\mathrm{H} 10$ & $2.33 \pm 0.57$ & $3 \pm 0.00$ & 0.184 \\
$\mathrm{H} 12$ & $1.33 \pm 0.57$ & $2 \pm 0.00$ & 0.423 \\
$\mathrm{H} 14$ & $1 \pm 0.00$ & $1.33 \pm 0.57$ & - \\
\hline
\end{tabular}

Keterangan:

$\mathrm{B} 1=$ Anak babi 1 sayatan (Rata-rata \pm standar deviasi)

B2= Anak babi 2 sayatan (Rata-rata \pm standar deviasi)

lebih cepat mengalami persembuhan luka dibandingkan dengan luka kastrasi dua sayatan (lihat Tabel 4), hal ini di pengaruhi karena ukuran luka yang berbeda. Menurut Pang et al. (2017) banyak faktor yang mempengaruhi proses persembuhan luka salah satunya karakteristik luka itu sendiri seperti kontaminasi atau ukuran luka, kelainan spesifik pada kaskade penyembuhan seperti jalur pensinyalan atau ekspresi gen kelainan, atau fisiologi pasien secara keseluruhan seperti penyakit sistemik atau immunodeficiency.

\section{UCAPAN TERIMA KASIH}

Penulis mengucapkan terima kasih utamanya kepada Divisi Bedah dan Radiologi, Departemen Klinik Reproduksi dan Patologi, Fakultas Kedokteran Hewan, Institut Pertanian Bogor, serta semua pihak yang telah membantu dalam penyelesaian penelitian ini.

"Penulis menyatakan tidak ada konflik kepentingan dengan pihak-pihak yang terkait dalam penelitian ini".

\section{DAFTAR PUSTAKA}

Amiruddin, Syafruddin, Zuraidawati, Desky R, Siregar TN, Sayuti A, Harris A. 2015. Pengaruh pemberian getah buah papaya dan povidone iodine terhadap kesembuhan luka kastrasi pada kucing. J Med Vet. 9(1):44-45.
Dewiyanti, A., Ratnawati $\mathrm{H}$, dan Puradisastra S. 2009. Perbandingan pengaruh ozon getah jarak cina (Jatropha multifida, L.) dan povide iodine 10\% terhadap waktu penyembuhan luka pada mencit betina galur swiss webster. JMH. 8(2):132-137.

Febram B, Wientarsih I, Pontjo B. 2010. Aktivitas sediaan salep batang pohon pisang ambon (Musa paradisiacalvar Sapientum) dalam proses penyembuhan luka pada mencit (Mus Musculus albinus). Maj Obat Trad. 15(3):121-137.

Fossum TW. 2019. Small Animal Surgery 5th Edition. Philadelphia (US): Elsevier.

Haris RA. 2009. Efektivitas penggunaan iodin 10\%, iodin $70 \%$, iodin $80 \%$, dan $\mathrm{NaCl}$ dalam percepatan proses penyembuhan luka pada punggung Tikus jantan Sprague Dawley [Skripsi]. Solo (ID): Universitas Muhammadiyah Surakarta.

Jitowiyono S, Kristiyanasari W. 2010. Asuhan Keperawatan Post Operasi. Yogyakarta (ID): Nuha Medika.

Kalangi SJR. 2014. Histofisiologi kulit. Jurnal Biomedik. 5(3): 12-20.

Kurniawaty E, Farmitalia CG, Rahmanisa S, Andriani S. 2018. Perbandingan tingkat kesembuhan luka sayat terbuka antara pemberian laktat dan pemberian propolis secara topikal pada tikus putih (Rattus norvegicus). Prosiding. Seminar Nasional Pakar ke 1 Tahun 2018. Hlm 339-345.

Kuswati K, Ravenska R, Hapsari N, Yekti AP, Susilawati T. 2016. Pengaruh kastrasi terhadap performan produksi sapi persilangan wagyu berdasarkan umur yang berbeda. JIIP. 26(3):53-58.

Landén NX, Li D, Ståhle M. 2016. Transition from inflammation to proliferation: a critical step during wound healing. Cellular and Molecular Life Sci, 73(20):3861-3885. 
Nurani D, Keintjem F, Losu FN. 2015. Faktor-faktor yang berhubungan dengan proses penyembuhan luka post sesectio caesarea. JIB. 3(1):1-6.

Østevik L, Elmas C, Luis M. Rubio-Martinez. 2012. Castration of the Vietnamese pot-bellied boar: 8 cases. Can Vet J. 53:943-948.

Marti S, Genswein KS, Janzen ED, Meléndez DM, Gellatly D, Pajor EA. 2017. Use of topical healing agents on scrotal wounds after surgical castration in weaned beef calves. Can Vet J. 58:1081-1085.

Pang C, Ibrahim A, Bulstrode NW, Ferretti P. 2017. An overview of the therapeutic potential of regenerative medicine in cutaneous wound healing. Int Wound J. 1742-4801.

Primadina N, Basori A, Perdanakusuma DS. 2019. Proses penyembuhan luka ditinjau dari aspek mekanisme seluler dan molekuler. Jurnal Qanun Medika (3)1: 31-43.

Priyanto L, Abrar A, Muslim G, Pratama ANT, Thernado RF. 2019. Perbedaan teknik kastrasi terhadap obot badan, panjang dan volume skrotum pada sapi bali. JPS. 8(2):1-8.

Qomariah S. 2014. Efektivitas salep ekstrak batang patah tulang (Euphorbia tirucalli) pada penyembuhan luka sayat tikus putih (Rattus norvegicus) [skripsi]. Semarang (ID): Universitass Negeri Semarang.

Rahmiati DU, Wismandanu O, Anggaeni K. 2020. Kontrol populasi dengan kegiatan sterilisasi kucing liar di lingkungan Unpad. Dharmakarya. 9(2):114-116.

Schottenhammer. 2020. Peruvian balsam an example of transoceanic transfer of medicinal knowledge. JEE. 16:69.

Suriadi. 2004. Perawatan Luka Edisi I. Jakarta (ID): CV. Sagung Seto.

Sutherland MA, Davis BL, Brooks TA, McGlone JJ. 2010. Physiology and behavior of pigs before and after castration: effects of two topical anesthetics. Int J animal sci. 4(12): 2071-2079.

Syukur C, Hermani. 2002. Budi Daya Tanaman Obat Komersil. Jakarta (ID): Penebar Swadaya.

Taylor CR, Lillis C, LeMone P, Lynn P,_LeBon M. 2011. Fundamental of Nursing the Art and Science of Nursing Care. Philadelphia (US): Lippincott Williams \& Wilkins.

Theresa WF, Duprey LP, Huff TG, Dewey CW. 2013. Small Animal Surgery. Missouri (US): Mosby Elsevier. 